[учебное пособие] / Н.В. Кузьмина. - Л. : ЛГУ, 1980. - 431 с.

8. Райцев А.В. Развитие профессиональной компетентности студентов в образовательной системе современного вуза: дис. ... доктора пед. наук: 13.00.08/ Райцев Анатолий Васильевич. - СПб., 2004. - 309 с.

9. Самойленко П.И. Формирование инженерно-технической деятельности среднего звена технического профиля / П.И. Самойленко, Т.В. Герищ // Стандарты и мониторинг в образовании. - 2005. - №5. - С.28-32.

10. Суворов В.С. Как формировать конкурентоспособного специалиста / В.С. Суворов, П.Н. Осипов. - Казань : ИСПО РАО, 2000. - 111 с.

11. Чечель И.Д. Реализация американской модели регионального колледжа в России / И.Д. Чечель // Директор школы. - 1993. - №1. - 16 с.

Стаття надійшла до редакції 03.06.2012 р.

УДК 37.026.8:009+375.5

I. С. Павленко, здобувач,

Криворізький педагогічний інститут ДВНЗ «Криворізький наиіональний університет»

\title{
ДИДАКТИЧНІ МОЖЛИВОСТІ ПРОЦЕСУ ВИВЧЕННЯ ГУМАНІТАРНИХ ДИСЦИПЛІН У КОНТЕКСТІ ФОРМУВАННЯ ЗАГАЛЬНОКУЛЬТУРНОЇ КОМПЕТЕНТНОСТІ УЧНІВ СТАРШОЇ ШКОЛИ
}

\begin{abstract}
Павленко I. С. Дидактичні можливості процесу вивчення гуманітарних дисциилін у контексті формування загальнокультурної компетентності учнів старшої иколи.

У статті висвітлено основні аспекти сучасного психолого-педагогічного розуміння дидактичних можливостей процесу вивчення гуманітарних дисииплін у контексті формування загальнокультурної компетентності учнів старшої школи. Визначено культурологогуманістичну функцію як провідну щодо формування загальнокультурної компетентності.

Ключові слова: дидактичні можливості, гуманітарні дисципліни, формування загальнокультурної компетентності, загальнокультурна компетентність учнів старшої школи.

Павленко И. С. Дидактические возможности процесса изучения гуманитарных дисииплин в контексте формирования общекультурной компетентности учащихся старших классов.

В статье освещены основные аспекты современного психолого-педагогического понимания дидактических возможностей процесса изучения гуманитарных дисииплин в контексте формирования общекультурной компетентности учащихся старшей школь. Культуролого-гуманистическая функиия определена как основная в отношении формирования общекультурной компетентности.
\end{abstract}

Ключевые слова: дидактические возможности, гуманитарные дисциплины, формирование общекультурной компетентности, общекультурная компетентность учащихся старшей школь.

Pavlenko I. Teaching opportunities process study of humanities in the context of general cultural competence High School Students.

The main aspects of modern psychological-and-pedagogical clarifying didactic potential possibilities concealed in the process of humanities studying in the context of forming high-school pupils' universal culture competence. Culture-and-humanity function is defined as a prime one in the regard of forming universal culture competence.

Key words: didactic potential possibilities, humanities, forming universal culture competence, high-school pupils' universal culture competence.

Вивчення й аналіз історичного досвіду показує, що значущість і впливовість гуманітарного знання не завжди вимірюються реальними, 
«очевидними» досягненнями. Вони можуть бути й наслідком різнофакторних чинників. Замислюючись над значенням гуманітарного знання взагалі та значенням гуманітарних дисциплін у загальноосвітній підготовці учнів старшої школи філософи, соціологи, педагоги підкреслюють не лише його культурну, а й індивідуальну соціальну цінність, оскільки гуманітарні дисципліни нині повною мірою виконують культуролого-гуманістичну функцію, за Л. Крившенко, яка полягає в розвитку духовних сил, здатностей і вмінь, що дозволяють людині з гідністю розв’язувати різноманітні за рівнем складності проблеми, формувати характер і моральну відповідальність за прийняття певних рішень, забезпечувати можливість для особистісного та професійного зростання, самореалізації, опанування засобами, необхідними для досягнення інтелектуально-моральної свободи, особистої автономії тощо.

Отже, коли йдеться про (а) - постановка проблеми) визначення дидактичних можливостей процесу вивчення гуманітарних дисциплін щодо формування однієї $з$ ключових компетентностей учнів - загальнокультурної компетентності - маємо спиратися, перш за все, саме на визначену культуролого-гуманістичну функцію як домінантну.

(б) - аналіз останніх досліджень $i$ nублікацій) Українські дидакти запропонували перелік ключових компетентностей і тим самим окреслили стратегічні напрями подальшого розвитку дидактичних науковотеоретичних і науково-практичних досліджень у нашій країні. До згаданого переліку ключових компетентностей віднесено: уміння вчитись, соціальна компетентність, загальнокультурна компетентність, здоров'язберігаюча компетентність, компетентності 3 інформаційних i комунікаційних технологій, громадянська компетентність, підприємницька компетентність.

Отже, загальнокультурна компетентність є однією 3 ключових компетентностей, які маємо формувати в учнів на кожному 3 етапів перебування й навчання в середній загальноосвітній школі. Старша школа це останній i найбільш важливий період щодо формування особистісних якостей учня, оскільки підлітковий вік на порозі юнацтва - той час, коли дорослі мають подбати про інтелігентність і загальну культуру особистості. I гуманітарній освіті в старшій школі відведено провідне й домінантне місце щодо розв'язання визначених задач. Саме тому маємо ретельно проаналізувати дидактичні можливості гуманітарних дисциплін у контексті формування загальнокультурної компетентності учнів старшої школи. Перш ніж зупинитись на кожному аспекті детально слід окреслити коло питань, пов’язаних зі змістом поняття «загальнокультурна компетентність».

Як визначають у своїй колективній монографії «Компетентнісний підхід у сучасній освіті: світовий досвід та українські перспективи» іiі автори Н. Бібік, Л. Ващенко, О. Локшина, О. Овчарук, Л. Паращенко, О. Пометун, О. Савченко, С. Трубачева: «Загальнокультурна компетентність стосується сфери розвитку культури особистості та суспільства у всіх ii аспектах, що передбачає передовсім формування культури міжособистісних відносин, 
оволодіння вітчизняною та світовою культурною спадщиною, принципи толерантності, плюралізму ...». Спираючись на запропоноване визначення, можемо стверджувати, що саме у процесі вивчення гуманітарних дисциплін можемо максимально забезпечити дидактичні умови формування загальнокультурної компетентності учнів старшої школи.

Виходячи $з$ цього мета даної роботи полягає (в) - формулювання изілей cmammi) у здійсненні грунтовного психолого-педагогічного аналізу сучасного розуміння дидактичних можливостей процесу вивчення гуманітарних дисциплін у контексті формування загальнокультурної компетентності учнів старшої школи..

(г) - виклад основного матеріалу дослідження) У сучасній гуманітаристиці ситуація $\epsilon$ постмодерністською, тобто такою, що характеризується фундаментальними змінами у формах мислення та спрямуванні дослідницьких інтересів. Показовими рисами мислення людини епохи постмодерну є толерантність і плюралізм, без яких неможливе здорове творче змагання в науці й культурі. На зміну змісту та формі викладу наукових знань, за В. Андрієвською, значно впливає зміна форми інформаційної ситуації у вітчизняному просторі. Збільшився доступ до новітньої зарубіжної літератури (наукової, художньої), розширилося уявлення про наукову роботу. Поряд із освоєнням постмодерністських здобутків у гуманітаристиці (постструктуралізм, постпозитивізм, новий лінгвістичний поворот тощо) в українському гуманітарному просторі активно освоюються класичні західні здобутки, недоступні широкому загалу десять-двадцять років тому. Вплив на учнів мають не лише дисципліни, а й сучасні філософські, педагогічні, соціологічні дослідження. Тож основа та змістове підгрунтя вивчення гуманітарних дисциплін $є$ доволі розмаїтим.

Власне дидактичні можливості процесу вивчення гуманітарних дисциплін реалізуються через низку взаємовпливів: дидактичного впливу 3 боку вчителя на учня під час уроку-лекції, уроку-семінару, уроку-диспуту, уроку-дискусії, уроку-презентації, під час надання вчителем додаткових індивідуальних і групових консультацій, під час керівництва індивідуальними, груповими інтерактивними проектами, під час використання різних форм контролю, через роботу у проблемних групах, учнівських наукових гуртках, i, звичайно, під час безпосереднього спілкування в навчальній і позанавчальній діяльності.

Сучасний учень старшої школи, який вивчає гуманітарні дисципліни, створює дидактичний контекст шляхом власних виступів і доповідей на уроках 3 елементами інновацій, спрямованих на формування найрізноманітніших компетентностей, у тому числі, звичайно, й загальнокультурної, яку, за певного узагальнення, можна вважати провідною щодо вивчення гуманітарних дисциплін, оскільки найбажанішим результатом цього процесу можна визнати формування інтелігентної, культурної особистості. Ставлячи відповідні питання викладачу під час індивідуальних, групових, інтерактивних та інших консультацій (а ці питання, як правило, виникають у результаті самостійної 
роботи 3 різноманітними джерелами інформації), безпосередньо під час самостійної та наукової роботи, контрольованої вчителем, а також використовуючи сучасні мультимедійні засоби й Internet. Як свідчить особистий досвід викладання гуманітарних дисциплін у старшій школі, зокрема іноземних мов та зарубіжної літератури, найбільш ефективним дидактичний взаємовплив буде в тих випадках, коли вчитель природнім шляхом, базуючись на власній педагогічній кваліфікації залучає учнів до процесу пізнання та впливає на учня силою гуманітарної науки й педагогічного досвіду в цілому, що аналізується з наукових і науково-практичних позицій.

Кожен аспект дидактичного взаємовпливу наповнюється реальним змістом у залежності від кожної окремої гуманітарної дисципліни, яка вивчається, характеру навчальних занять, індивідуальних особливостей учнів старшої школи. І в такому випадку вчитель здебільшого використовує «дидактичний вплив через справу» [4, с. 27], а до впливу на себе з боку учнів ставиться з розумною обачливістю й тактом.

Зауважимо, що в одній зі своїх робіт Ю. Лотман, характеризуючи суспільні тенденції, виділяє чинник різкого зниження комунікативності, що створює ситуацію, за якої взаєморозуміння між окремими особистостями ускладнюється аж до повної ізольованості, становить, безперечно, соціальну хворобу. Численні суспільні й особисті трагедії, що походять від цього, не мають потреби в їх переліку [8, с. 200]. Період вивчення молодою людиною гуманітарних дисциплін дозволяє запобігти цим негативним тенденціям, здійснити своєрідне «щеплення» від «зниження комунікативнсті».

Дисципліни гуманітарного циклу умовно об’єднані спільним дослідницьким полем, оскільки для них одиницею вивчення й дослідження є текст (М. Бахтін [1]). Дослідники різноманітних семіотичних комунікативних структур відзначають таку закономірність: якщо вибудувати у послідовності наростання складності текстової структури ланцюжок - повідомлення у повсякденному (наприклад, вуличному) середовищі - текст природною мовою - творення поетичного чи прозового твору, то очевидно, що перше може бути тільки однозначно зрозумілим одержувачем повідомлення, друге - орієноване на однозначне («правильне») розуміння, але припускає випадки двозначності, а третє, по суті, виключає можливість однозначності. Тож процес вивчення гуманітарних дисциплін сам по собі сприяє формуванню культурної людини, яка навчена за період навчання сприймати події, явища як багатозначні, багатопланові, плюралістичні, ідеї та продукцію гуманітарних наук засвоювати з позицій критичного підходу, розуміючи їх «умовність» (К. Поппер [7]). Така людина добре розуміється на особливостях дидактичної взаємодії, здатна долати труднощі, пов'язані 3 індивідуальними чи груповими особливостями тих, кого навчають, уникати догматизму та стереотипізації, урахувати особливості індивідуального сприйняття учнями певного тексту тощо. Саме ці якості учнів старшої школи стають провідними в сучасних умовах, адже відмова від унітарного характеру освіти автоматично призвела до розмаїття навчальних програм, підручників, посібників, орієнтуватися в яких та обирати 
певні $з$ них варто, ураховуючи повний спектр дидактичного контексту (рівень навчального закладу, рівень навченості учнів, особливості комплектування класу та інше), керуючись настановою про те, що людина як особистість стає сама собою й може бути собою лише на межі зі світом «інших», а не в ізоляції від нього: «Усе значиме, важливе відбувається на межі своєї й чужої свідомості» [3, с. 102]. Діалогічність гуманітарного знання сприяє досягненню взаєморозуміння, узгодженості при виконанні різних видів навчальної роботи, накопиченню досвіду праці, пізнання та спілкування, а такий досвід у кожної людини завжди індивідуально своєрідний (О. Бодальов [2]).

Є. Пасічник цілком слушно зауважував, що нинішній учитель почуває себе більш розкутим в організації навчального процесу, аніж це було раніше: у попередні роки при незрівнянно кращому забезпеченні вчителя методичною літературою й художніми книгами він не міг себе повністю реалізувати [6, с. 11]. Але досягається ця «розкутість» саме на грунті формування загальнокультурної компетентності. Варто також підкреслити іманентність компетентнісного підходу саме для вивчення гуманітарних дисциплін. Так, О. Усик пише про те, що, оскільки компетентісний підхід пов'язаний 3 ідеєю всебічної підготовки й виховання індивіда не лише як спеціаліста своєї справи, але й як особистості, члена колективу й соціуму, він $є$ гуманітарним у своїй основі. Адже метою гуманітарної освіти є не лише передача учню сукупності знань, умінь і навичок у певній гуманітарній сфері, а й розвиток світогляду, міждисциплінарного чуття, здатності до прийняття індивідуальних творчих рішень, до самоосвіти, а також формування гуманістичних цінностей [9, с. 18-19].

Традиційно вітчизняна педагогіка взагалі та дидактика зокрема визнавали фактично лише соціальну сутність суб'єкта навчання - учня, з цього гасла слідувало, що метою освіти $є$ формування соціально значимих якостей, розвиток людини як члена суспільства. Та людина осягає свою сутність, осягаючи культуру; культурна сутність людини $\epsilon$ системоутворювальним компонентом їі цілісності, за висловом Є. Бондаревської.

Отже, (д) - висновки) гуманітарні дисципліни як ретранслятори культурних надбань людства завжди персоніфіковані, звернені до кожного суб’єкта навчання й у теперішньому, й у майбутньому. Відродити «гуманітарну ауру нації» (Л. Костенко) спроможні виключно студенти гуманітарних дисциплін. Зважаючи на катастрофічний стан мовно-літературної освіти в нашій країні, учителям, які викладають гуманітарні дисципліни в старшій школі, слід бути обізнаними щодо особливостей дидактичного контексту викладання гуманітарних дисциплін і мати чіткі уявлення про значення, специфіку й особливості предметів гуманітарного циклу.

\section{Література}

1. Бахтин М. М. Вопросы литературы и эстетики. Исследования разных лет / Михаил Михайлович Бахтин. - М. : Художественная литература, 1975. - 504 с.

2. Бодалев А. А. Психология общения / Алексей Александрович Бодалев. - М. : Изд-во «Институт практической психологии», Воронеж НПО «МОДЭК», 1996. - 256 с. 
3. Волкова Е. В. Тона и обертоны серьезного в философии М. Бахтина / Е. В. Волкова, С. 3. Оруджаева. // Вопросы философии. - 2000. - №1. - С. 102-118.

4. Кобиляцький I. I. Методи навчально-виховної роботи у вищій школі / Іван Іванович Кобиляцький. - Л. : Вид-во ЛДУ, 1979. - 230 с.

5. Компетентнісний підхід у сучасній освіті : світовий досвід та українські перспективи: бібліотека з освітньої політики : [монографія] / Н. М. Бібік, Л. С. Ващенеко, О. І. Локшина та ін.; [під заг ред. О. В. Овчарук]. - К. : К. І. С., 2004. - 112 с.

6. Пасічник С. А. Методика викладання української літератури в середніх навчальних закладах : [навч. пос.] / С. А. Пасічник.- К. : Ленвіт, 2000. - 384 с.

7. Поппер К. Логика и рост научного знания / Карл Поппер. - М. : Прогресс, 1983. - 606 с.

8. Сучасна літературна компаративістика : стратегії і методи. Антологія / [за заг. ред. Д. Наливайка]. - К. : Вид.дім «Києво-Могилянська академія», 2009. - 487 с.

9. Усик О. Ф. Формування соціокультурної компетентності студентів філологічних спеціальностей у процесі вивчення гуманітарних дисциплін : дис. ... канд. пед. наук : 13.00.09. / Олена Федорівна Усик - К. : Інститут педагогіки АПН України, 2010. - 275 с.

Стаття надійшла до редакції 03.06.2012 p.

\section{ПСИХОЛОГО-ПЕДАГОГІЧНИЙ АНАЛІЗ СТАНОВЛЕННЯ КОНЦЕПЦІЙ НАВЧАЛЬНО-ПІЗНАВАЛЬНОЇ ДІЯЛЬНОСТІ СТУДЕНТІВ ЯК ОСНОВА ДИДАКТИЧНОЇ ІНТЕНСИФІКАЦІї (РЕТРОСПЕКТИВНИЙ ОГЛЯД: ХVII - початок XX ст.)}

Малихіна С.В. Психолого-педагогічний аналіз становлення концепцій навчальнопізнавальної діяльності студентів як основа дидактичної інтенсифікаиії (ретроспективний огляд: XVII - початок XX ст.).

У статті висвітлено основні положення здійсненого психолого-педагогічного аналізу становлення концепцій навчально-пізнавальної діяльності студентів як основи дидактичної інтенсифікації (представлено ретроспективний огляд з часів становлення сучасної педагогіки в XVII столітті й до початку XX).

Ключові слова: психолого-педагогічний аналіз, навчально-пізнавальна діяльність студентів, дидактична інтенсифікаиія, ретроспективний аналіз.

Мальхина С.В. Психолого-педагогический анализ становления концепиий учебнопознавательной деятельности студентов как основа дидактической интенсификации (ретроспективный обзор: XVII - начало XX cm.).

В статье освещены основные положения проведенного психолого-педагогического анализа становления концепций учебно-познавательной деятельности студентов как основы дидактической интенсификаиии (представлено ретроспективное обозрение со времен становления современной педагогики в XVII столетии и до начала XX).

Ключевые слова: психолого-педагогический анализ, учебно-познавательная деятельность студентов, дидактическая интенсификация, ретроспективный анализ.

Malykhina V. Psycho-pedagogical analys is of the formation of concepts learning and cognitive activity of students as the basis for the didactic intensification (retrospective review: XVII - beginning of $X X$ century).

The principal statements of the psychological-and-pedagogical analysis concerning the problem of uprising the conceptual theories investigating students' learning and cognitive activities are illuminated in the article. The activities are regarded as the foundations for the didactic intensification (the results of some retrospective survey comprising the period from the birth time of Pedagogy in the $X V I I^{\text {th }}$ century and till the beginning of the $X X^{\text {th }}$ are represented). 